\title{
Left Coronary Artery Branch
}

National Cancer Institute

\section{Source}

National Cancer Institute. Left Coronary Artery Branch. NCI Thesaurus. Code C32958.

Any artery arising from the left coronary artery. 